\title{
Swiprosin-1 Promotes Mitochondria- Dependent Apoptosis of Glomerular Podocytes via P38 MAPK Pathway in Early-Stage Diabetic Nephropathy
}

\author{
Rong-Mei Wang ${ }^{a, b}$ Zhi-Bin Wang ${ }^{b} \quad$ Yue Wanga,b Wei-Ye Liu ${ }^{b} \quad$ Ya Lia,b \\ Ling-Chang Tong ${ }^{b}$ Su Zhang ${ }^{a, b}$ Ding-Feng Su ${ }^{b}$ Yong-Bing Cao ${ }^{c}$ Ling $\mathrm{Li}^{\mathrm{b}, \mathrm{c}}$ \\ Li-Chao Zhang ${ }^{\mathrm{a}}$ \\ aDepartment of Pharmacy, Shanghai Municipal Hospital of Traditional Chinese Medicine, Shanghai, \\ bDepartment of Pharmacology, College of Pharmacy, Second Military Medical University, Shanghai, \\ 'Shanghai institute of vascular disease of integrated traditional Chinese and western medicine, \\ Shanghai traditional Chinese medicine-integrated hospital, Shanghai, China
}

\section{Key Words}

Diabetic nephropathy $\bullet$ Podocyte $\cdot$ Apoptosis $•$ Swiprosin-1 $•$ P38 MAPK

\begin{abstract}
Background/Aims: Podocyte injury, especially podocyte apoptosis, plays a major role in earlystage diabetic nephropathy (DN). Swiprosin-1, also known as EF hand domain containing 2 (EFhd2), is a $\mathrm{Ca}^{2+}-$ binding protein in different cell types. However, the function of swiprosin-1 in podocytes remains unknown. Methods: The expression and distribution of swiprosin-1 were investigated in the mouse renal glomerulus and conditionally immortalized mouse podocyte cell line MPC-5. The expression of swiprosin-1 was also detected in streptozotocin (STZ)-treated mice and MPC-5 cells treated with high glucose (HG). Nephrin and podocin were detected by immunohistochemistry and immunofluroscence. Collagen IV, transforming growth factor- $\beta$ (TGF- $\beta$ ) and fibronectin mRNA expressions were assayed by real-time PCR. Apoptotic proteins and phosphorylation of p38 mitogen-activated protein kinase (MAPK) were detected by immunoblotting. Results: Swiprosin-1 was found to be expressed in podocytes of the mouse glomerulus and MPC-5 cells. Swiprosin-1 expression was increased in STZ-treated mice and MPC-5 cells treated with HG. In Swiprosin-1\% diabetic mice, kidney/ body weight, urinary albumin, podocyte foot process effacement and glomerular basement membrane thickening were attenuated; the downregulation of nephrin and podocin expression in the glomerulus was inhibited; and the upregulation of collagen IV, TGF- $\beta$ and fibronectin mRNA expression in the renal cortex was ameliorated as compared with those in diabetic swiprosin-1 $1^{+/+}$mice. In addition, the increased apoptosis of podocytes, proapoptotic protein expression and p38 phosphorylation in Swiprosin-1\% diabetic mice were inhibited as compared with those in diabetic swiprosin-1 $1^{+/+}$mice. Knockdown of swiprosin-1 in MPC-5 cells

R. Wang, Z. Wang and Y. Wang contributed equally to this study

Ling Li

and Li-Chao Zhang

Department of Pharmacology, College of Pharmacy, Second Military Medical University, Department of Pharmacy, Shanghai Municipal Hospital of Traditional Chinese Medicine (China); Tel. 0086-21-65493951, E-Mail lingli_z163@163.com,changhaiskin@163.com
\end{abstract}

\section{KARGER}


Wang et al.: Swiprosin-1 Promotes Podocyte Apoptosis in Early DN

reduced the apoptosis of podocytes, proapoptotic protein expression and p38 phosphorylation induced by HG. Targeted knockdown of p38 attenuated the increased apoptosis of MPC-5 cells over-expressing swiprosin-1. Conclusion: Swiprosin-1 expression in podocytes of the mouse glomerulus played a critical role in early-stage DN. Swiprosin-1 deficiency in early DN attenuated mitochondria-dependent podocyte apoptosis induced by hyperglycemia or HG via p38 MAPK signaling pathway.

(C) 2018 The Author(s)

Published by S. Karger AG, Basel

\section{Introduction}

Diabetic nephropathy (DN) is the most common cause of end-stage renal disease worldwide, mainly characterized by extra-cellular matrix (ECM) accumulation, glomerular basement membrane (GBM) thickening and podocyte injury [1-3]. ECM accumulation and GBM thickening used to be considered as the primarily important mechanisms in the pathogenesis of DN. However, evidence in recent years indicates that podocytes are critical cells for maintaining the renal filtration barrier and preventing albuminuria, playing an important role in the development of renal diseases [4-6]. Podocyte damage, such as alterations in the structure of podocytes or loss of podocytes will affect the integrity of the glomerular filtration barrier, resulting in proteinuria, thus promoting the progression of DN $[7,8]$. Accumulating evidence indicates that DN is more like a "podocyte disease" [9-11]. Some clinical studies $[12,13]$ showed that the number of podocytes was reduced by detachment, or apoptosis as the primary reason. As podocytes are terminally differentiated epithelial cells and located in the glomerular basement membrane, their apoptosis is associated with their inability to be replaced or regenerated, ultimately resulting in glomerulosclerosis. Although podocyte apoptosis plays a major role in early-stage DN, the underlying molecular pathogenesis remains unclear.

Swiprosin-1, also known as EF hand domain containing 2 (EFhd2), was initially identified as a novel protein in human $\mathrm{CD}^{+}$lymphocytes [14], and subsequently in immature, resting or activated B cells [15-17], macrophages and natural killer cells [18, 19], and non-lymphoid tissues such as the brain, spleen, lung, liver and heart [17, 20, 21]. In murine B cells, ectopic expression of swiprosin-1 was found to enhance spontaneous and B-cell receptor induced apoptosis [16, 22]. In addition, swiprosin-1 was found to be involved by signaling cascades involving $\mathrm{Ca}^{2+}[19,20]$, protein kinase $\mathrm{C}$, and nuclear factor- $\kappa \mathrm{B}[23]$. Also, swiprosin-1 was reported to be involved in the process of caspase-9-protein complexes in non-small cell lung cancer (NSCLC) cells and may promote caspase- 9 activation, which may be linked to cell apoptosis [24].

In a study we conducted previously we could show that swiprosin-1 was also expressed in the mouse brain, heart, stomach and kidney [25]. Here, we further found that swiprosin-1 was predominantly expressed in podocytes of the mouse glomerulus and was up-regulated in the kidney of 8-week-old diabetic mice. These results indicated that swiprosin-1 expressed in glomerular podocytes might be involved in early-stage DN. Considering that swiprosin-1 was also shown to be involved in apoptosis, we hypothesized that swiprosin-1 might be a crucial protein in podocyte apoptosis in early-stage DN.

In this study, we firstly sought to investigate whether and how swiprosin-1 promoted podocyte apoptosis in vivo and in vitro in the glomerulus of diabetic mice and conditionally immortalized mouse podocyte cell line MPC-5 treated with high glucose (HG); further explore the signaling pathway of swiprosin-1 in early-stage DN; and finally examine whether p38 mitogen-activated protein kinase (MAPK) was activated by swiprosin-1 in vivo and in vitro.

\section{Materials and Methods}

Materials

The main materials used in this study were streptozocin (STZ) (Sigma-Aldrich, St Louis, MO, USA); Cell Counting Kit-8 (CCK-8) and JC-1 mitochondrial membrane potential assay kit (Beyotime, Shanghai, China); 


\section{Cellular Physiology Cell Physiol Biochem 2018;45:899-916 \begin{tabular}{l|l|l} 
and Biochemistry & DOI: 10.1159/000487285 & $\begin{array}{l}\text { C) } 2018 \text { The Author(s). Published by S. Karger AG, Basel } \\
\text { www.karger.com/cpb }\end{array}$ \\
\hline
\end{tabular}}

Lipofectamine 2000 reagent (GenePharma, Shanghai, China); antibodies against swiprosin-1 and podocin (Santa Cruz, Dallas, TX, USA); nephrin (Boster, Wuhan, China); cleaved caspase-8, Wilms Tumor 1 (WT1, Novus biochemisry, Colorado, America); cleaved caspase-3 (Abcam, Cambridge, UK); cleaved caspase-9, Bax, Bcl-2, cytochrome C, total p38 and phospho-p38 (Cell Signaling Technology, Boston, MA, USA); tubulin (Beyotime, Shanghai, China); SB203580(Selleck Chemicals, Texas, America); BCA protein quantification kit (Bi-yun-tian, Shanghai); Trizol reagent, PrimeScript RT Master Mix Perfect Real Time kit and FastStart Universal SYBR Green Master (Invitrogen, Carlsbad, CA, USA); type I collagen (Biochrom, Berlin, Germany); mouse recombinant interferon (IFN- $\gamma$ ) (Immugenex, Los Angeles, CA); RPMI 1640, fetal bovine serum (FBS) (GIBCO, Grand Island, NY); mannitol (Beijing Dingguo Changsheng Biotechnology, Beijing, China). All chemicals were purchased from Sigma-Aldrich.

\section{Animals}

C57BL/6J male mice weighing 18-22 g were purchased from the SLRC Laboratory Animal Lid (Shanghai, China).

Swiprosin-1 knockout mice were generated as described previously [16]. Recombineering was used to generate a gene targeting construct from a bacterial artificial chromosome (BAC) containing the swiprosin-1 gene (C57Bl/6J inbred strain). E14 ES cells were transfected with this construct, and successfully targeted ES cells were injected into $\mathrm{C} 57 \mathrm{Bl} / 6 \mathrm{~J}$ blastocysts. Mice bearing this targeted allele of exon 2-4 deletion in the germline were bred to generate swiprosin-1/-- mice.

All mice were kept under an automated $12 \mathrm{~h} / 12 \mathrm{~h}$ dark-light cycle at a controlled temperature of 22 ${ }^{\circ} \mathrm{C} \pm 2{ }^{\circ} \mathrm{C}$ and relative humidity of $50-60 \%$ and allowed free access to standard dry diet and tap water. All animals received humane care. All the experimental procedures were performed in accordance with the guidelines of the Second Military Medical University (Shanghai, China) for health and care of experimental animals.

\section{Diabetic models and specimen collection}

Firstly, $20 \mathrm{C} 57 \mathrm{BL} / 6 \mathrm{~J}$ male mice were equally randomized to two groups: control group (CON) and diabetic group (DM). Then 20 swiprosin-1 $1^{+/+}$mice and 20 swiprosin-1 $1^{-/-}$mice were divided into four groups respectively: swiprosin-1+/+ control group (WT-CON), swiprosin-1+/+ diabetic group (WT-DM), swiprosin-1/control group (KO-CON), and swiprosin-1//- diabetic group (KO-DM). Mice in all diabetic groups were treated by a single injection of $150 \mathrm{mg} / \mathrm{Kg}$ STZ intraperitoneally (i.p.) [26], and mice in control groups received the sodium-citrate vehicle correspondingly. After $72 \mathrm{~h}$, diabetes was confirmed in STZ-treated mice by measuring plasma glucose via the tail vein (random blood glucose value $>16.7 \mathrm{mM}$ ). After 8 weeks, all mice were killed to harvest the kidneys.

\section{Serum cystatin $C$ assay}

Serum cystatin $\mathrm{C}$ is known as an ideal marker of the glomerular filtration rate (GFR). ELISA for mouse serum cystatin C assay (Abnova, Neihu District. Taipei City) was used according to the manufacturers' protocol.

\section{Urinary albumin}

Urinary albumin was detected as described previously [10]. Using metabolic cages, $24 \mathrm{~h}$ urine samples were collected, centrifuged at 12, $000 \mathrm{~g}$ for $15 \mathrm{~min}$, and diluted with buffer solution at 1:2000. Urinary albumin was detected by ELISA according to the protocol of Mouse Urinary Albumin Detection Kit (Chondrex, Redmond, WA, USA).

\section{Cell culture}

Conditionally immortalized mouse podocyte cell line MPC-5 was purchased from ATCC (Maryland, USA). Cells were propagated on type I collagen at $33^{\circ} \mathrm{C}$ with $50 \mathrm{U} / \mathrm{mL}$ IFN- $\gamma$. Then cells were transferred to and incubated at $37^{\circ} \mathrm{C}$ without IFN- $\gamma$ for 10-14 days for differentiation. The culture medium was RPMI 1640 with 10\% FBS. When cells reached about $80 \%$ confluence, siRNA transfection was conducted, followed by 48-h treatment with $33 \mathrm{mM}$ D-glucose (HG) or $5.5 \mathrm{mM}$ D-glucose (NG) as control. Finally, cells were harvested for Western blot or other studies. 


\section{Cellular Physiology Cell Physiol Biochem 2018;45:899-916 and Biochemistry Published \begin{tabular}{l|l} 
DOI: 10.1159/000487285 & 2018 The Author(s). Published by S. Karger AG, Basel \\
www.karger.com/cpb
\end{tabular}}

Wang et al.: Swiprosin-1 Promotes Podocyte Apoptosis in Early DN

siRNA transfection and treatment

SiRNA transfection was performed as described previously [27]. Cells were seeded at $2 \times 10^{5} /$ well in 6-well plates, incubated overnight at $37^{\circ} \mathrm{C}$, and then transfected with $75 \mathrm{pM}$ siRNA (GenePharma, shanghai, China), Opti-MEM I Reduced Serum Medium and Lipofectamine 2000 complex. The sequences are as follows: siRNA-swiprosin-1(si-Swi), 5'-GCCGCUUUGAGGAAGAGAUTT-3', and 5'-AUCUCUUCCUCAAAGCGGCTT-3'; siRNA-p38 (si-p38), 5'-GGUCACGGAGGAAUUCAATT-3' and 5'-UUGAAUUCCUCCAGUGACCTT-3'; negative control siRNA (Con), 5'-UUCUCCGAACGUGUCACGUTT-3' and 5'-ACGUGACACGUUCGGAGAATT-3'. After 6 h, transfected cells were washed, cultured for $24 \mathrm{~h}$ in complete medium, stimulated with HG or NG for $48 \mathrm{~h}$, and finally harvested for analysis.

\section{Lentivirus construction and preparation}

CDS sequence (residues 54-776 in the murine Swiprosin-1 cDNA sequence, GenBank accession number NM_025994.3) was synthesized to construct LV-GFP as negative control. The recombinant lentivirus expressing swiprosin-1 full-length coding sequence (LV-Swi) was produced by Shanghai Innovation Biotechnology Co., Ltd (Shanghai, China). The virus was concentrated by ultracentrifugation and titred by infection of confluent 293T cells.

\section{Cell viability assay}

Cell viability was indirectly evaluated by CCK-8 assay. Differentiated MPC- 5 cells were seeded in a 96well plate at a density of $2 \times 10^{3} /$ well. After $48 \mathrm{~h}$ incubation in medium containing different concentrations of D-glucose (5.5-33 mM), cells were treated with $10 \mu \mathrm{LCCK}-8$ solution for $1 \mathrm{~h}$ at $37^{\circ} \mathrm{C}$. Optical density (OD) was measured at $450 \mathrm{~nm}$ with a microplate reader. The result was calculated as the mean value of five wells for each group, and the assay was performed in triplicate.

\section{Protein extraction and immunoblotting}

Immunoblotting was detected as described previously [28]. Briefly, MPC-5 cells or kidney tissues were washed with cold phosphate buffer saline (PBS), and then lysed in protein extraction reagent containing protease and phosphatase inhibitor cocktail. The mixture was centrifuged at $12,000 \mathrm{~g}$ for $15 \mathrm{~min}$ at $4{ }^{\circ} \mathrm{C}$, and the protein concentration of the supernatant was determined by Bradford method. After being mixed with loading buffer, the sample was boiled at $98^{\circ} \mathrm{C}$ for $5 \mathrm{~min}$. An equal amount of protein was separated by $12.5 \%(\mathrm{w} / \mathrm{v})$ sodium dodecyl sulfate-polyacrylamide gel electrophoresis (SDS-PAGE) and transferred to the nitrocellulose membrane, which was blocked for $3 \mathrm{~h}$ at room temperature with the blocking reagent and then incubated with the primary antibodies overnight at $4{ }^{\circ} \mathrm{C}$. Tubulin was diluted at 1:5000, and the other antibodies were diluted at 1:1000. Then the membrane was incubated with corresponding secondary antibodies (1:5000 dilution) for $30 \mathrm{~min}$ at room temperature. Odyssey infrared imaging system (LI-COR, Lincoln, NE, USA) was used to analyze the results. All immunoblotting experiments were repeated at least three times.

\section{Immunohistochemical staining}

The kidneys were perfused with ice cold saline before being collected from the animals. The renal tissues were formalin-fixed, paraffin-embedded and cut into 4-5 $\mu \mathrm{m}$ sections. Then sections were deparaffinized and rehydrated. To unmask antigens, the slides were boiled at $100{ }^{\circ} \mathrm{C}$ for $10 \mathrm{~min}$ in $10 \%$ citrate buffer (pH 6.0). After blocking with the buffer (PBS, $2 \%$ BSA, 10\% FBS) for $1 \mathrm{~h}$, the slides were incubated with antibodies against swiprosin-1(1:100) and nephrin $(1: 100)$ overnight at $4{ }^{\circ} \mathrm{C}$, and then incubated with secondary antibody (1:100). The immunoreaction products were developed using diaminobenzidine (DAB) as the chromogen, with standardized development times. The sections were examined by microscopy. For quantitative analysis, 3-6 glomeruli per group of per animal in each experiment were analyzed. Nephrinpositive cells were quantified by counting five different fields at $400 \times$ magnification in each section.

\section{Electron microscopy}

Electron microscopy was performed as described previously [29]. The renal tissues from the mice in each group were perfused with ice cold saline before collection, then rapidly cut into small (1-3 $\left.\mathrm{mm}^{3}\right)$ pieces and fixed in $2.5 \%$ glutaraldehyde. The pieces were thin sectioned and collected in grids. Two grids for each animal were prepared and five animals per group were analyzed. The ultrastructural features of podocytes were observed under the electron microscope. 


\section{Cellular Physiology Cell Physiol Biochem 2018;45:899-916 and Biochemistry Published \begin{tabular}{l|l} 
DOI: 10.1159/000487285 & $\begin{array}{l}\text { () } 2018 \text { The Author(s). Published by S. Karger AG, Basel } \\
\text { www.karger.com/cpb }\end{array}$
\end{tabular}}

Wang et al.: Swiprosin-1 Promotes Podocyte Apoptosis in Early DN

\section{Immunofluorescence staining}

Immunofluorescence staining of the kidney specimens was performed as described previously [30]. The kidneys were perfused with ice cold saline before being collected from the animals. The slides were fixed, incubated with antibodies swiprosin-1 (1:100), WT-1 (1:100) and podocin $(1: 100)$ overnight at 4 ${ }^{\circ} \mathrm{C}$, washed, incubated with corresponding Alexa Fluor 488 or 549 secondary antibody (1:200; Molecular Probes, Eugene, OR, USA) in dark for $2 \mathrm{~h}$ at room temperature, mounted, and observed under a fluorescence microscope.

For immunofluorescence staining of differentiated MPC-5 cells, samples were fixed with $4 \%$ paraformaldehyde in PBS for 10 min, blocked in $0.4 \%$ Triton-X-100/2\% bovine serum albumin (BSA) for 1 $\mathrm{h}$, incubated with primary antibodies for swiprosin- 1 and nephrin in $1 \% \mathrm{BSA} / \mathrm{PBS}$ at $37^{\circ} \mathrm{C}$ for $2 \mathrm{~h}$, washed, incubated with fluorescence conjugated secondary antibodies for $1 \mathrm{~h}$ at $37^{\circ} \mathrm{C}$ in dark, washed again, dried, and incubated with DAPI. The images were analyzed by fluorescence microscopy.

TUNEL assay

The apoptosis rate of cells in the mouse renal cortex and cultured podocyte cells was measured using a One Step TUNEL Apoptosis Assay Kit (KeyGEN BioTECH, Nanjing, China) according to the manufacturer's instructions. Apoptosis was defined as the presence of TUNEL-positive podocytes within glomeruli. The mean percentage of TUNEL-positive podocytes in podocytes of per glomerulus in the formalin-fixed renal section was determined by examining 6-8 glomeruli from the group studied. Images were analyzed by fluorescence microscopy (Olympus Corporation, Tokyo, Japan) or by confocal microscopy (Leica DMLB, Wetzlar, Germany).

\section{Apoptosis analysis by flow cytometry}

Cell apoptosis was analyzed using Annexin V-FITC apoptosis kit (eBioscience, Santiago, CA, USA) or Alexa Fluor@647 Annexin V apoptosis kit (using for lentivirus transfected cells, Biolegend, San Diego, CA). As described previously [31], total cells $\left(1 \times 10^{6}\right.$ cells/well $)$ were collected through centrifugation and then resuspended in $500 \mu \mathrm{L}$ binding buffer. Then, $100 \mu \mathrm{L}$ solution containing $1 \times 10^{5}$ cells was added to a $5 \mathrm{~mL}$ tube with $5 \mu \mathrm{L}$ Annexin V- FITC and $5 \mu \mathrm{L}$ PI. All samples were incubated at room temperature in the dark for 10 min. Cell samples were analyzed by flow cytometry conducted with FACScan (Becton, Dickinson and Company, Franklin, NJ, USA) within $1 \mathrm{~h}$.

\section{Quantitative Real-time PCR}

Total RNA of the kidney tissue was extracted with Trizol reagent by following the instructions of the manufacturer. After reverse transcription, complementary DNA was used as template for PCR. Gene expression was detected by RT-qPCR using SYBR Green qPCR Master Mix. Primers for the cytokines and internal reference gene were as follows: TGF- $\beta$, forward, 5'-AGGGCTACCATGCCAACTTC-3', reverse, 5'-CCACGTAGTAGACGATGGGC-3'; CollagenIV: forward, 5'-AACAACGTCTGCAACTTCGC-3', reverse, 5'-CTTCACAAACCGCACACCTG-3'; fibronectin: forward, 5'-CCCCAACTGGTTACCCTTCC-3', reverse, 5'-TGTCCGCCTAAAGCATGTT-3'; GAPDH:forward, 5'-GTATGACTCCACTCACGGCAAA-3', reverse, 5'-GGTCTCGCTCCTGGAAGATG-3'. The complete RT-PCR procedure was repeated 3 times.

\section{Mitochondrial membrane potential ( $\triangle \Psi \mathrm{m})$ detection}

Differentiated podocytes were washed with PBS, incubated with JC-1 (10 mg/mL) at $37{ }^{\circ} \mathrm{C}$ for 20 min and washed twice with PBS. Mitochondrial membrane potentials were monitored using a confocal Microscope (Leica DMLB, Wetzlar, Germany). JC-1 monomer fluorescence (green) was observed at $488 \mathrm{~nm}$ laser excitations and emissions at $530 \mathrm{~nm}$. JC-1 aggregate fluorescence (red) was observed at $525 \mathrm{~nm}$ laser excitations and emissions at $590 \mathrm{~nm}$. Six areas in each cultured dish were scanned and the mean intensity for each region was evaluated. The ratio of JC-1 aggregate to monomer intensity for each region was calculated.

\section{Statistical analysis}

All quantified data were expressed as means \pm SD. Parameters between two groups were compared by unpaired Student's t-tests. Data involving more than two groups were assessed by analysis of variance (ANOVA). Values of $\mathrm{p}<0.05$ were considered statistically significant. Statistical analysis was performed using SPSS (Version 18.0 for Windows, SPSS Inc., Chicago, IL, USA). 


\section{Cellular Physiology Cell Physiol Biochem 2018;45:899-916

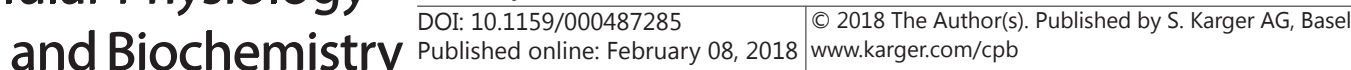

Wang et al.: Swiprosin-1 Promotes Podocyte Apoptosis in Early DN

\section{Results}

\section{Swiprosin-1 expression in mouse glomerular podocytes}

As shown in Fig. 1A, swiprosin-1 was expressed in the mouse kidney by immunoblotting. To further study the localization of swiprosin-1 in the kidney, the kidney sections were stained with swiprosin-1 antibody. It was found that swiprosin-1 was widely expressed in mouse glomeruli (Fig. 1B). In addition, immunofluorescence showed that swiprosin-1 distributed around WT-1 in mouse glomeruli (Fig. 1C). As WT-1 is a marker of podocytes and expressed in the nucleus [32-34], the above results indicate that swiprosin-1 was expressed in podocytes of mouse renal glomeruli. As shown in Fig. 1D, swiprosin-1 was expressed in MPC- 5 cells. To unravel the potential function of swiprosin- 1 in the kidney, we studied the intracellular localization of swiprosin-1 and found that swiprosin-1 was co-localized with nephrin and mainly localized at the membrane and cytoplasm of differentiated MPC-5 cells by immunofluorescence (Fig. 1E). Knowing that nephrin is a key protein of the slit diaphragm located at the differentiated podocytes [35-37], these results suggest that swiprosin-1 was expressed in podocytes.

Swiprosin-1 expression is up-regulated in diabetic mice and increased in podocytes treated with high glucose

The diabetic mice developed severe albuminuria and presented pathologic changes characteristic of DN such as glomerular hypertrophy and extracellular matrix deposition from 8 weeks after modeling (Fig. 2). Compared with control group, swiprosin-1 protein level was increased in the renal cortex of the diabetic mice in 8 weeks (Fig. 3A and B). Similarly, immunofluorescence analysis showed that swiprosin- 1 staining was augmented in the diabetic kidney compared with that in control group (Fig. 3C).

There was no significant difference in swiprosin-1 expression between normal glucose (GS, $5.5 \mathrm{mM}$ ) and medium containing mannitol treated MPC-5 podocytes (GS+M group, Fig. 2D), indicating that the influence of osmotic pressure could be eliminated. The expression of swiprosin-1 was increased in podocytes after stimulation with medium containing glucose at $22 \mathrm{mM}(2.18 \pm 0.27)$ for $48 \mathrm{~h}$, continuously increased at $33 \mathrm{mM}(2.89 \pm 0.33)$, and $44 \mathrm{mM}$ $(3.13 \pm 0.10)$ than that in normal glucose $(N G, 5.5 \mathrm{mM}, 1.00 \pm 0.08)$. Furthermore, there was no significant difference in swiprosin-1 expression in podocytes after stimulation with high glucose (HG, $33 \mathrm{mM}$, Fig. 2E) for 12 and $24 \mathrm{~h}$ as compared with control group $(1.00 \pm 1.15)$. But the expression of swiprosin- 1 was increased at $48 \mathrm{~h}(2.07 \pm 0.13)$ and $72 \mathrm{~h}(2.35 \pm 0.12)$ and $96 \mathrm{~h}(2.45 \pm 0.11)$.

In addition, the podocyte viability was decreased in $22 \mathrm{mM}(0.27 \pm 0.02$, Fig. $2 \mathrm{~F})$ glucose treated podocytes for $48 \mathrm{~h}$, continuously decreased at $33 \mathrm{mM}(0.24 \pm 0.03)$ and 44 $\mathrm{mM}(0.23 \pm 0.04)$ compared with control group (5.5 mM, 0.35 \pm 0.06$)$. As shown in Fig. 3G, compared with NG-treated podocytes, the podocyte viability was decreased after stimulation with HG $(33 \mathrm{mM})$ for $48 \mathrm{~h}(0.33 \pm 0.01$ vs. $0.39 \pm 0.03), 72 \mathrm{~h}(0.34 \pm 0.01 v s .0 .51 \pm 0.03)$ and $96 \mathrm{~h}$ $(0.52 \pm 0.09$ vs. $0.60 \pm 0.02)$.

\section{Swiprosin-1 mediates podocyte apoptosis in vivo and in vitro}

To investigate the effect of swiprosin-1 in podocytes, we created diabetes models in swiprosin-1/++ and swiprosin-1\% mice. As shown in Fig. 4A, the immunohistochemistry results revealed that the expression of swiprosin-1 in swiprosin-1 $1^{+/+}$mice was increased compared with that in swiprosin-1\% mice. Compared with diabetic swiprosin-1//+ mice, there were some differences in general pathological characteristics, such as body weight reduction, glomerular hypertrophy and ECM accumulation in diabetic swiprosin-1\% mice. In addition, diabetic swiprosin-1\% mice exhibited a significant increase in serum CST3, and a decrease in kidney/body weight and urinary albumin as compared with those in diabetic swiprosin-1 $1^{+/+}$ mice (Fig. 4). As shown in Fig. 5A, B and C, GBM thickening and degradation or fusion of the podocyte foot process were increased in swiprosin-1 ${ }^{+/+}$diabetic mice compared with those in swiprosin-1 ${ }^{+/+}$control group (GBM: $484.75 \pm 31.48 \mathrm{~nm} v$ s. $213.75 \pm 2.13 \mathrm{~nm}$, podocyte foot 
Fig. 1. Swiprosin-1 expression in mouse glomerular podocytes. Representative Western blot and quantitative analyses for swiprosin-1 in the mouse renal tissue were shown. Kidney sections were treated with (B) immunohistochemistry and (C) immunofluorescence. Differentiated MPC-5 cells were treated with (D) Western blot and (E) immunofluorescence. Images are representative of 5 mice in each group. Scale bars are $10 \mu \mathrm{m}$ in immunohistochemistry staining; scale bars are $10 \mu \mathrm{m}$ in immunofluorescence staining. Data are shown as mean \pm SD. ${ }^{*} \mathrm{p}<0.05,{ }^{* *} \mathrm{p}<0.01$ vs. control group or as indicated.

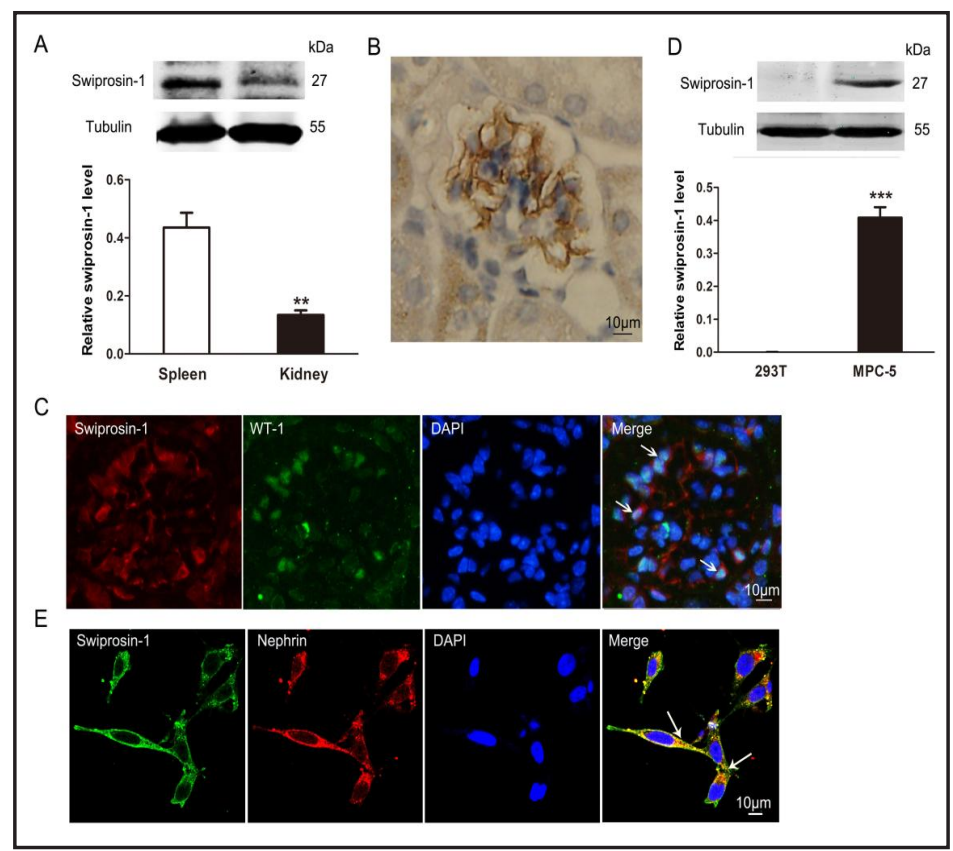

Fig. 2. General characteristics of diabetic mice. (A) PAS staining in the renal glomerulus (B) body weight (C) kidney/body weight (Kidney/body wt) (D) blood glucose (E) urinary albumin (F) serum cystatin $C$ were shown with or without STZ injection in C57BL/ 6 mice for 8 weeks. Arrows indicate mesangial and endocapillary hypercellularity. CON, control; DM, diabetes mellitus. Scale bars are $10 \mu \mathrm{m}$. Data are expressed as mean \pm SD. ( $n=10$ in each group) $* \mathrm{p}<0.05$, $* * \mathrm{p}<0.01$ vs. CON group.

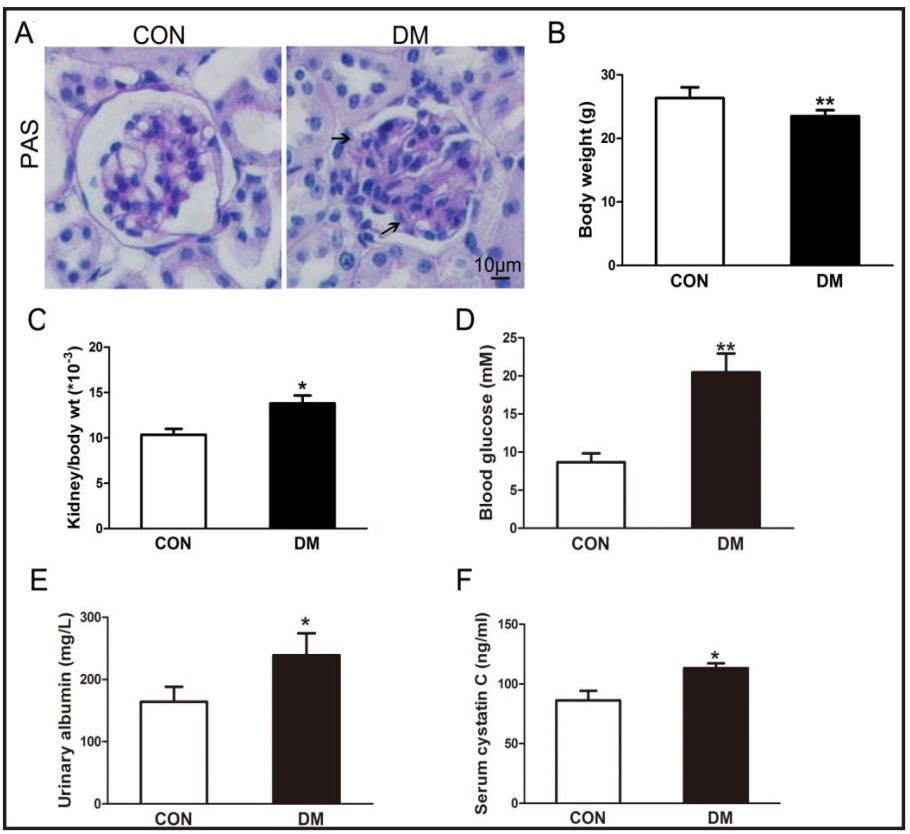

process width: $664.94 \pm 86.13 \mathrm{~nm} v s .273 .50 \pm 9.45 \mathrm{~nm}$ ). There was no significant difference between WT-CON group and KO-CON group. However, GBM thickening and effacement of the podocyte foot process were attenuated in swiprosin-1\% diabetic mice compared with swiprosin-1/++ diabetic mice (GBM: $305.50 \pm 19.57 \mathrm{~nm}$ vs. $484.75 \pm 31.48 \mathrm{~nm}$, podocyte foot process width: $429.33 \pm 29.91 \mathrm{~nm} v s .664 .94 \pm 86.13 \mathrm{~nm}$ ). The results of TUNEL staining in WT-1 positive cells revealed that the apoptotic rate of podocytes in diabetic swiprosin-1 $1^{+/+}$ mice was increased compared with that in swiprosin-1//+ control mice

$(3.33 \pm 0.88 \%$ vs. $13.35 \pm 0.89 \%)$. There was no significant difference in the apoptotic rate of podocytes in the kidney compared between swiprosin- 1 knockout mice and wildtype mice under normal conditions. However, the increased apoptotic rate of podocytes was attenuated in diabetic swiprosin-1\% mice compared with that in diabetic swiprosin-1 $1^{+/+}$mice (8.1 $\pm 0.57 \%$ vs. $13.35 \pm 0.89 \%$, Fig. 5D and E).

\section{KARGER}




\section{Cellular Physiology \begin{tabular}{ll|l} 
and Biochemistry & Published online: February 08, 2018 & $\begin{array}{l}\text { (c) } 2018 \text { The Author(s). Published by S. Karger AG, Basel } \\
\text { www.karger.com/cpb }\end{array}$ \\
\hline
\end{tabular}

Fig. 3. Swiprosin-1 expression was up-regulated in diabetic mice and podocytes treated with high glucose. (A, B) Representative blot and (C) immunofluorescence for swiprosin-1 expression in the kidney with or without STZ injection in C57BL/6 mice for 8 weeks. Representative blots of three independent experiments are shown. Images are representative of 5 mice in each group. Scale bars are $10 \mu \mathrm{m}$. CON, control; DM, diabetes mellitus. (D) Representative blot of swiprosin-1 expression in differentiated MPC-5 cells treated with different concentrations $(5.5,11,22,33$ and $44 \mathrm{mM})$ of glucose and mannitol (38.5 mM) with glucose $(5.5 \mathrm{mM})$ for $48 \mathrm{~h}$. (E) Representative blot of swiprosin-1 expression in differentiated MPC-5 cells treated with high glucose $(33 \mathrm{mM})$ for $0,12,24,48$ and 96h. (F) Representative cell viability was shown for differentiated MPC-5 cells treated with different concentration of glucose for $48 \mathrm{~h}$. (G) Representative cell viability was shown for differentiated MPC-5 cells treated with high glucose $(33 \mathrm{mM})$ or normal glucose $(5.5 \mathrm{mM})$ for $0,12,24,48$ and $96 \mathrm{~h}$. NG, normal glucose (5.5 mM); HG, high glucose $(33 \mathrm{mM})$; GS+M, $5.5 \mathrm{mM}$ glucose+38.5 mM mannitol. ${ }^{*} \mathrm{p}<0.05,{ }^{* *} \mathrm{p}<0.01$ compared with CON group or as indicated.

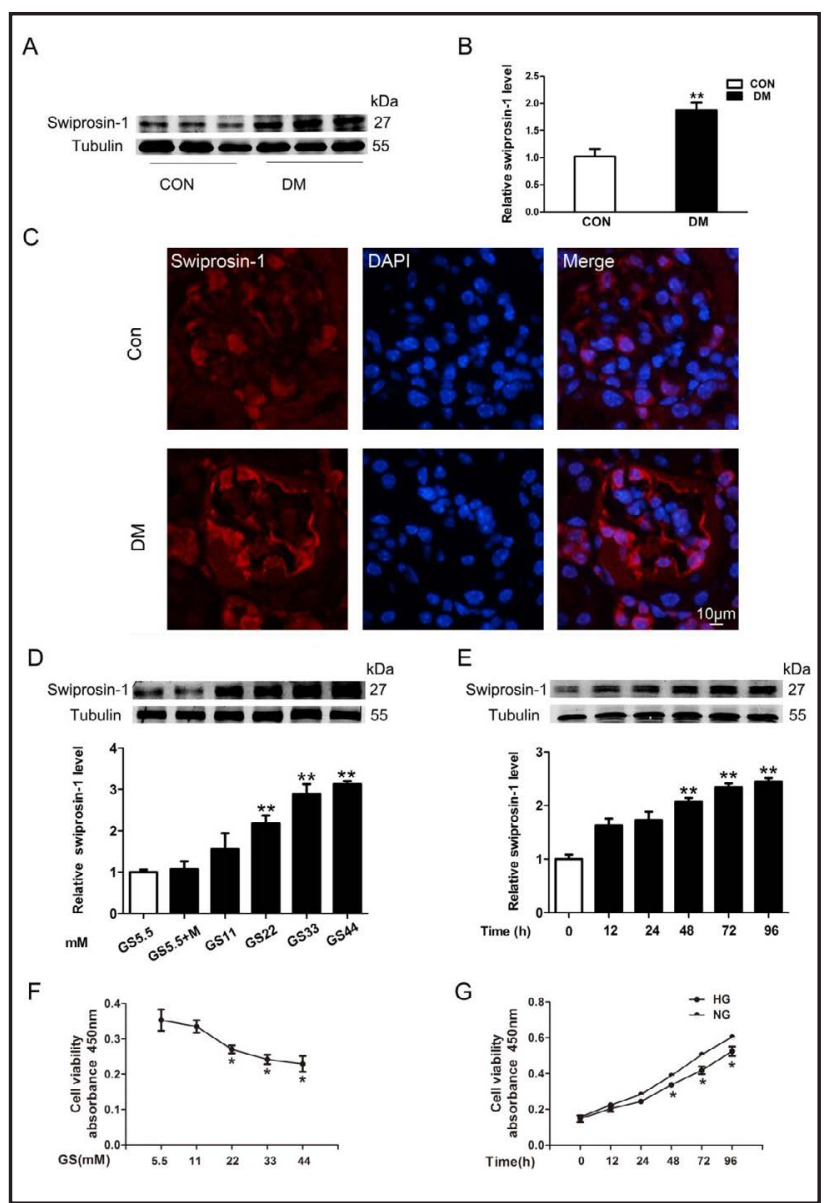

Then we performed in vitro experiments to examine the effects of swiprosin-1 on podocyte apoptosis induced by HG. As shown in Fig. 6A and B, the apoptotic rate of podocytes in CON-HG group was increased sharply by $16.63 \%$ as compared with that in Con-NG group $(25.64 \pm 0.99$ vs. $6.34 \pm 0.66)$, as shown by flow cytometry. There was no significant difference in apoptosis level between control podocytes and medium containing mannitol group (M+NG group), indicating that the influence of osmotic pressure on apoptosis level could be eliminated. Also, there was no significant difference in apoptosis level between podocytes transfected with the siRNA knockdown swiprosin-1 and control siRNA treated with NG. However, podocytes with swiprosin-1 knockdown inhibited the increase of the apoptosis rate compared with control siRNA podocytes treated with HG $(14.88 \pm 1.27 v s .25 .64 \pm 0.99)$.

Furthermore, JC-1 staining of mitochondrial membrane potential $(\Delta \psi \mathrm{m})$ showed no significant difference in the red/green fluorescence ratio between control podocytes and medium containing mannitol group ( $\mathrm{M}+\mathrm{NG}$ group), as well as control siRNA group (Fig. 6C and D). Compared with control group, the red/green fluorescence ratio in CON-HG group was significantly decreased $(1.007 \pm 0.06$ vs. $0.55 \pm 0.05)$. However, the decrease of the ratio was attenuated in podocytes with swiprosin-1 knockdown compared with that in control siRNA podocytes treated with HG $(0.55 \pm 0.05$ vs. $0.81 \pm 0.09)$.

These data indicate that swiprosin-1 knockdown might contribute to the reduced apoptosis of podocytes in both diabetic mice and MPC-5 cells after HG stimulation.

Deficiency of Swiprosin-1 attenuates podocyte injury in the kidney of diabetic mice

Down-regulation of podocyte-specific proteins is an indicator of podocyte injury [32]. As shown in Fig. 7A, B, C and D, the staining of nephrin and podocin was decreased significantly in the glomeruli of swiprosin-1 $1^{+/+}$diabetic mice as compared with that in swiprosin-1 $1^{+/+}$ 
Fig. 4. General characteristics of swipro$\sin -1^{+/+}$and swiprosin-1\% diabetic mice. (A) Immunohistochemistry of swiprosin-1 was shown in swiprosin-1 WT and KO mice. Arrows indicate the staining of swiprosin-1. Scale bars are $10 \mu \mathrm{m}$. (B) PAS staining in the kidney glomerulus was shown with or without STZ injection in swiprosin-1 WT and KO mice for 8 weeks. Arrows indicate mesangial and endocapillary hypercellularity. Scale bars are $10 \mu \mathrm{m}$. (C)Body weight (D) kidney/body weight (Kidney/Body wt) (E) blood glucose (F) urinary albumin (G) serum cystatin $C$ were shown with or without STZ injection in swiprosin-1 WT and KO mice for 8 weeks. CON, control; DM, diabetes mellitus. Data are expressed as mean \pm SD. $(n=10$ in each group) $* \mathrm{p}<0.05,{ }^{* *} \mathrm{p}<0.01$ vs. WT-CON group; \#p< $0.05 \# \# \mathrm{p}<0.01$ vs. WT-DM group.

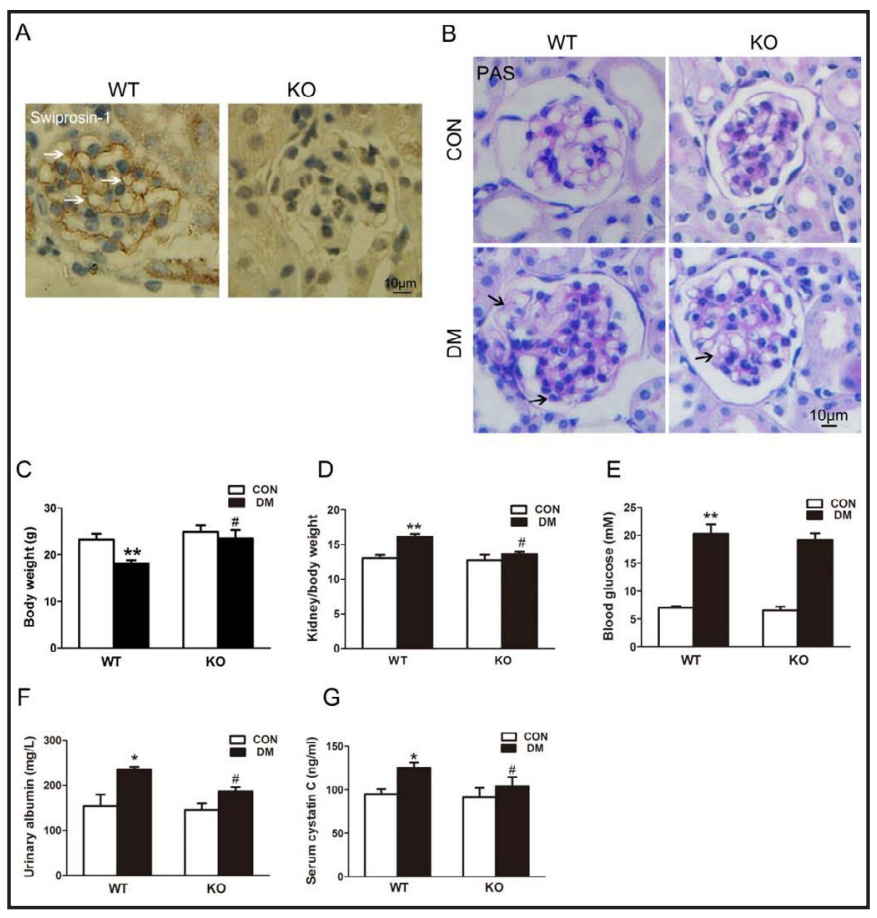

Fig. 5. Swiprosin-1 mediated podocyte apoptosis in vivo. Twenty swipro$\sin -1^{+/+}$mice and 20 swiprosin-1/-/ mice were divided into two groups: a swiprosin- $1^{+/+}$control group (WTCON) and a swiprosin-1 $1^{+/+}$diabetic group (WT-DM), a swiprosin-1/-/- control group (KO-CON) and a swiprosin-1/- diabetic group (KO-DM). (A) Representative electron microscopic images of glomeruli from control and diabetic swiprosin-1 WT and KO mice. Fine arrows indicate foot fusion and effacement. Thick arrows indicate GBM thickness. Scale bars are $50 \mu \mathrm{m}$. (B) Quantification of GBM thickness and (C) podocyte foot process effacement determined from 9 different fields ( $\mathrm{n}=5$, for each group). CON, control; DM, diabetes mellitus. ${ }^{*} \mathrm{p}<0.05,{ }^{* *} \mathrm{p}<0.01$ vs. WT-CON group, and $\# \mathrm{p}<0.05, \# \# \mathrm{p}<0.01$, \#\#\#p<0.001 vs. WT-DM group. (D) TUNEL staining in four groups. Arrows indicate cells counted as TUNEL positive. Scale bars are $10 \mu \mathrm{m}$. (E) Quantification of TUNEL positive cells was performed in a blinded fashion in 10 randomly selected glomeruli per animal $(n=5$, for each

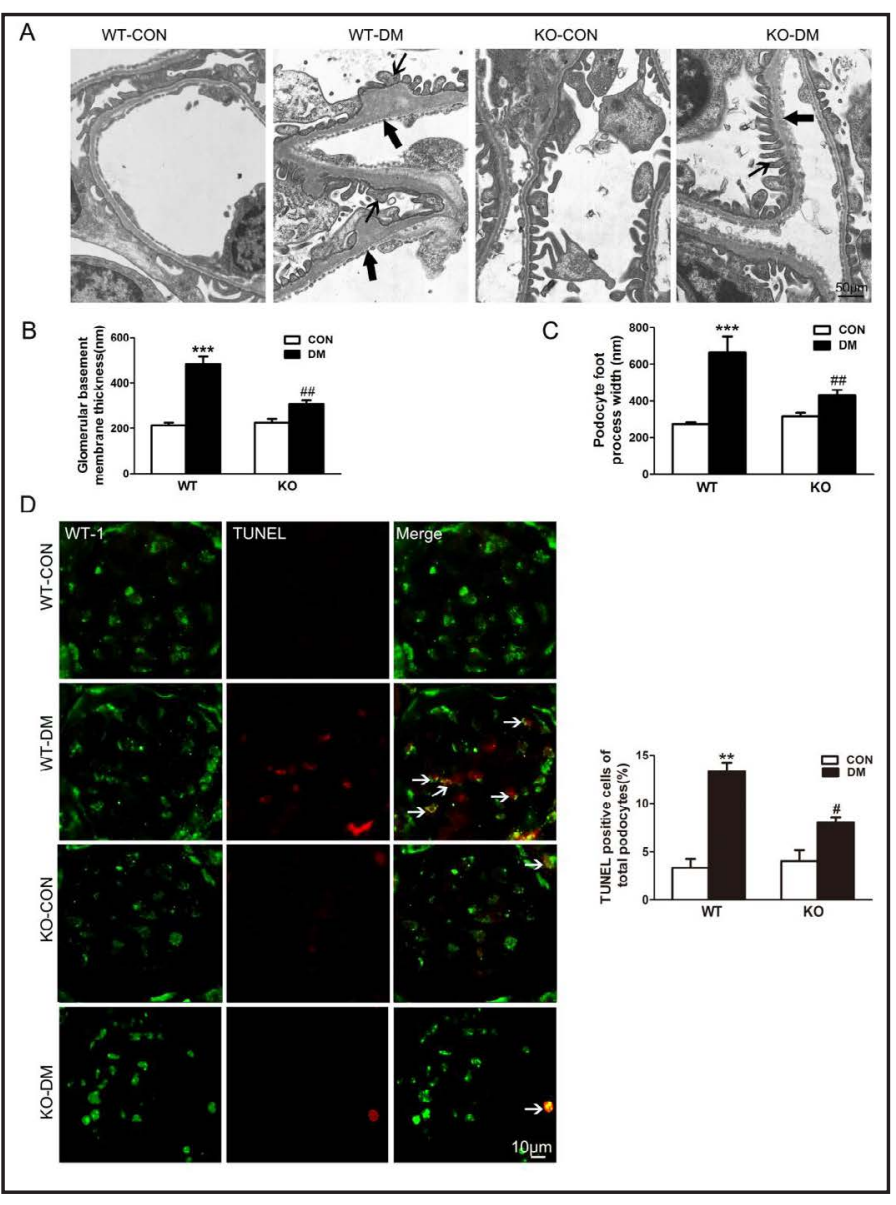
group). ${ }^{*} \mathrm{p}<0.05,{ }^{* *} \mathrm{p}<0.01$ vs. WT-CON group, and $\# \mathrm{p}<0.05$ vs. WT-DM group.

\section{KARGER}


Fig. 6. Swiprosin-1 mediated podocyte apoptosis in vitro. (A, B) The apoptosis rate of podocytes transfected with swiprosin-1-siRNA or negative control siRNA and treated with NG or HG for $48 \mathrm{~h}$ was measured by using Annexin V-FITC Apoptosis Analysis Kit. (C, D) The mitochondrial membrane potential of podocytes transfected with swiprosin-1-siRNA or negative control siRNA and treated with NG or HG for $48 \mathrm{~h}$ was measured by JC-1 staining. Con, negative control siRNA; si-Swi, swiprosin-1-siRNA; Con-M, $5.5 \mathrm{mM}$ glucose+38.5 mM mannitol. ${ }^{*} \mathrm{p}<0.05,{ }^{* *} \mathrm{p}<0.01$ vs. Con-NG group, $\# \mathrm{p}<0.05$ vs. Con-HG group.

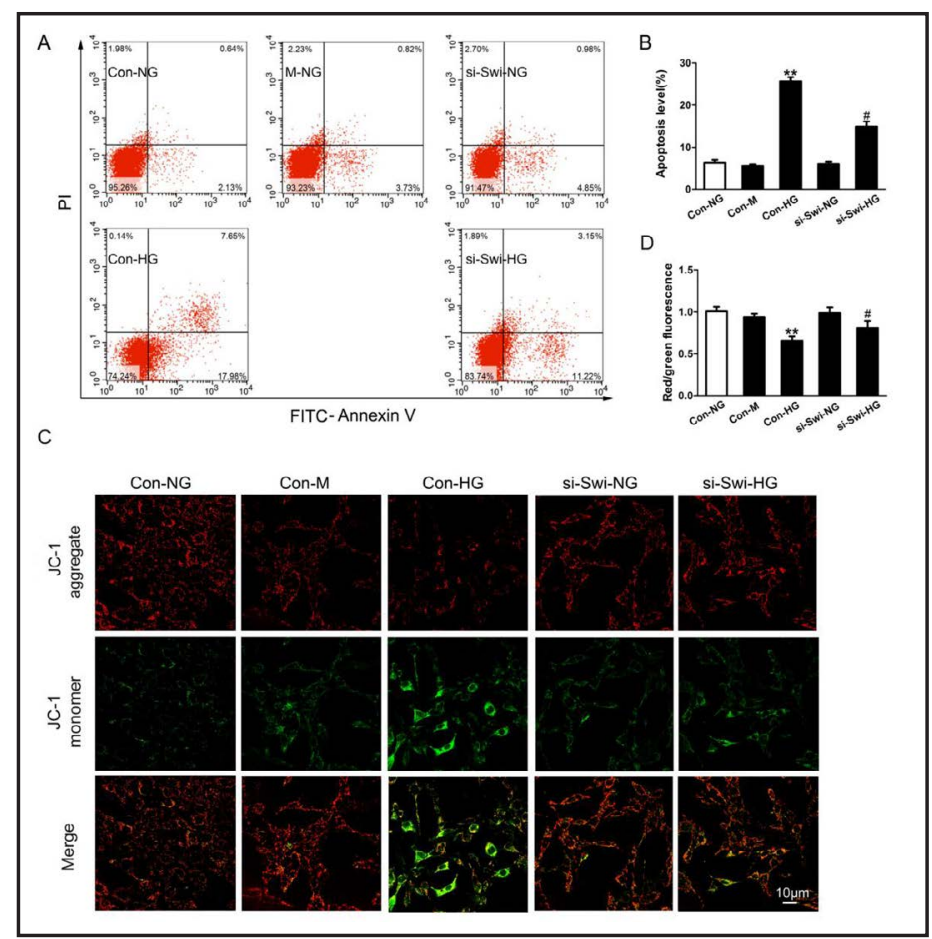

Fig. 7. Swiprosin-1 deficiency attenuated podocyte injury in the kidney of diabetic mice. (A, B) Immunohistochemistry of nephrin in mouse glomeruli of control and diabetic swiprosin-1 WT and KO mice were shown. Arrows indicate the staining of nephrin. Scale bars are $10 \mu \mathrm{m}$. (C, D) Immunofluorescence of podocin in mouse glomeruli of control and diabetic swiprosin-1 WT and KO mice were shown. Arrows indicate the staining of podocin. Scale bars are $10 \mu \mathrm{m}$. (E-G) mRNA levels of collagen IV, TGF- $\beta$ and fibronectin were determined using real-time PCR $(n=5$ per group). ${ }^{*} \mathrm{p}<0.05,{ }^{* *} \mathrm{p}<0.01$ vs. WT-CON group, and $\# \mathrm{p}<0.05, \# \# \mathrm{p}<0.01$ vs. WT-DM group.

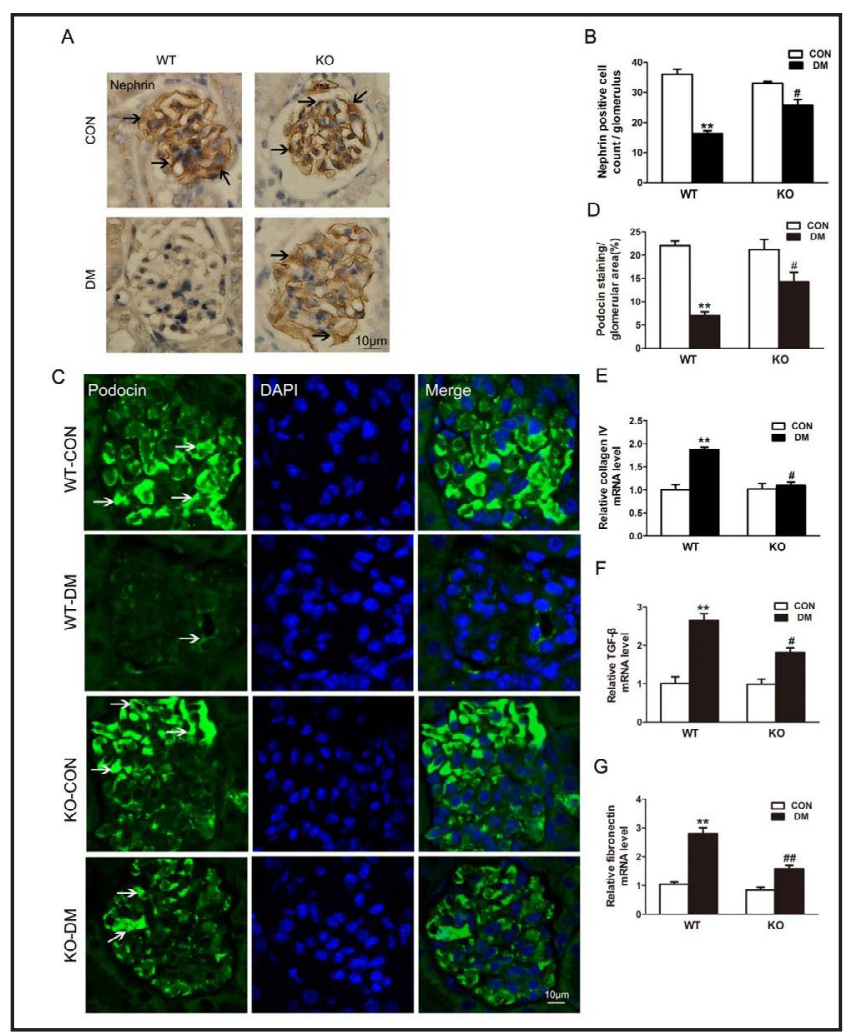

control mice (nephrin: $308.33 \pm 12.29$ vs. $150.64 \pm 14.64$, podocin: $6.97 \pm 0.88$ vs. $22.04 \pm 0.99$ ), indicating that the glomeruli were damaged in swiprosin-1 ${ }^{+/+}$diabetic mice. There was no significant difference in the staining of both podocin and nephrin in the glomeruli between wild-type and knockout control groups. While swiprosin-1\% diabetic mice showed increased staining compared with swiprosin- $1^{+/+}$diabetic mice (nephrin: $16.33 \pm 0.88$ vs. $25.67 \pm 2.03$, podocin: $14.23 \pm 2.09 v s$. $6.97 \pm 0.88$ ). 
Fig. 8. Swiprosin-1 induced podocyte mitochondria-dependent apoptosis. (A) Representative blots of cleavedcaspase8, cleaved-caspase3, cleavedcaspase9, Bax and bcl-2 proteins in the kidney tissue from control and diabetic swiprosin-1 WT and KO mice were shown. (B) Representative blots of cleaved-caspase8, cleavedcaspase3, cleaved-caspase9, Bax and bcl-2 proteins of differentiated MPC5 cells transfected with swiprosin1-siRNA or negative control siRNA and treated with NG or HG for $48 \mathrm{~h}$ were shown. CON, control; DM, diabetes mellitus; Con, negative control siRNA; si-Swi, swiprosin-1-siRNA. ${ }^{*} \mathrm{p}<0.05,{ }^{* *} \mathrm{p}<0.01$ vs. WT-CON or Con-NG group; \#p< 0.05, \#\#p<0.01, $\# \# \#$ p $<0.001$ vs. WT-DM or Con-HG group.
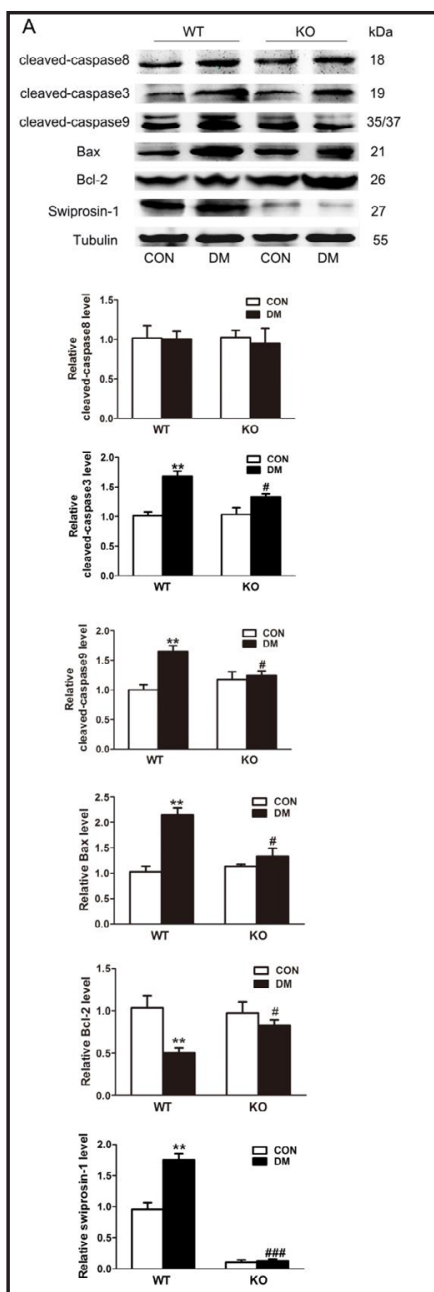
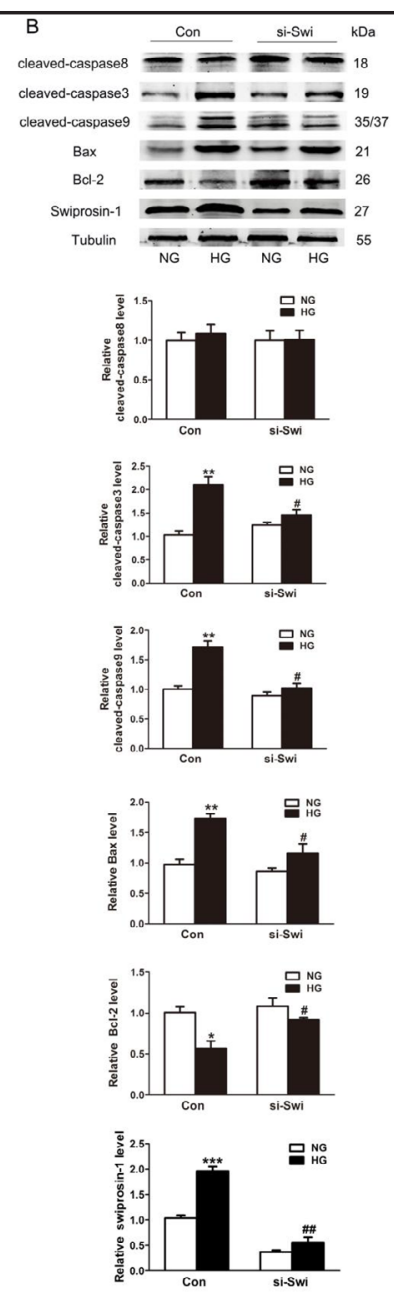

We also examined glomerular collagen IV, TGF- $\beta$ and fibronectin accumulation in diabetic mice. There was no significant difference in mRNA expression level of collagen IV, TGF- $\beta$, and fibronectin between WT-CON and KO-CON groups. Compared with swiprosin-1/++ control group, mRNA levels of collagen IV, TGF- $\beta$, and fibronectin were higher in the renal cortex of swiprosin-1 $1^{+/+}$diabetic mice. Compared with swiprosin-1 $1^{+/+}$diabetic mice, swiprosin- $1^{\%}$ diabetic mice inhibited the increase of collagen IV expression $(1.14 \pm 0.07 v s .1 .88 \pm 0.05$, Fig. 7E), TGF- $\beta(1.81 \pm 0.13$ vs. $2.64 \pm 0.18$, Fig. $7 F)$ and fibronectin $(1.59 \pm 0.11$ vs. $2.81 \pm 0.20$, Fig. $7 G)$.

\section{Swiprosin-1 induces podocyte mitochondria-dependent apoptosis}

There was no significant difference in the level of cleaved-caspase8 between WT-CON and KO-CON groups, as well as swiprosin- $1^{+/+}$control and swiprosin-1 $1^{+/+}$diabetic group (Fig. 8A). There was no significant difference in the level of pro-apoptosis proteins (cleavedcaspase3, cleaved-caspase 9 and Bax) between WT-CON and KO-CON groups. Compared with swiprosin-1 $1^{+/+}$control group, cleaved-caspase3, cleaved-caspase9, and Bax protein levels in swiprosin-1/++ diabetic mice were increased. Moreover, the expression of pro-apoptosis proteins in swiprosin-1\% diabetic mice was lower than that in swiprosin-1/++ diabetic mice. Additionally, Bcl-2 protein level was obviously decreased in diabetic swiprosin-1/++ mice as compared with that in swiprosin-1 $1^{+/+}$control mice. Compared with swiprosin-1 $1^{+/+}$control group, Bcl-2 protein expression was not significantly different in swiprosin-1\% control mice. However, the Bcl-2 protein level was increased in swiprosin-1\% diabetic mice compared with that in swiprosin-1+/+ diabetic mice. 
Fig. 9. Swiprosin-1 induced podocyte mitochondria-dependent apoptosis via p38 MAPK pathways. (A) Representative blots of phosphorylation p38 MAPK level of kidney tissue from control and diabetic swiprosin-1 WT and KO mice were shown. CON, control; DM, diabetes mellitus. (B) Representative blots of phosphorylation p38 MAPK level of differentiated MPC5 cells transfected with swiprosin1-siRNA or negative control siRNA and treated with NG or HG were shown. Con, negative control siRNA; si-Swi, swiprosin-1-siRNA. (C) Representative blots of p38 MAPK of differentiated MPC-5 cells transfected with p38-siRNA or negative control siRNA. si-p38, p38-siRNA. (D,E) Cell apoptosis rate of podocytes transfected with p38-siRNA or negative control siRNA and treated with $\mathrm{NG}$ or $\mathrm{HG}$ for $48 \mathrm{~h}$ were measured by using Annexin V-FITC apoptosis analysis kit. $(F, G)$ Cell apoptosis rate of podocytes treated with SB203580 and stimulated with $\mathrm{NG}$ or $\mathrm{HG}$ for $48 \mathrm{~h}$ were measured by using Annexin V-FITC apoptosis analysis kit. (H,I) Representative blots of swiprosin-1 protein level of differentiated MPC-5 cells transfected with lentiviruses expressing full-length swiprosin-1 (LV-Swi, LV-GFP as control) were shown. (J,K,L) The transfection efficiency and apoptosis rate of podocytes transfected with p38-siRNA or negative control siRNA and transfected with lentiviruses expressing full-length swiprosin-1 (LV-Swi, LV-GFP as control) for $48 \mathrm{~h}$ were measured by using Alexa Fluor 647-Annexin $V$ apoptosis analysis kit. ${ }^{*} \mathrm{p}<0.05,{ }^{* *} \mathrm{p}<0.01$ vs. WT-CON or as indicated; $\# \mathrm{p}<0.05, \# \# \mathrm{p}<0.01$ vs. WT-DM or as indicated.

As shown in Fig. 8B, there was no significant difference in the level of cleaved-caspase8 between control and HG-treated podocytes, as well as control siRNA tranfected cells and swiprosin-1 knockdown cells (Fig. 8B). In addition, the expression of active fragments of cleaved-caspase9, cleaved-caspase3, and bax in HG-treated podocytes was higher than that in control cells. However, compared with control siRNA tranfected cells, there was no obvious change in swiprosin-1 knockdown podocytes treated with normal glucose. It was markedly decreased in swiprosin-1 knockdown podocytes compared with that in control siRNA tranfected podocytes after HG stimulation. In addition, Bcl-2 protein expression was decreased in HG treated podocytes compared with that in control siRNA tranfected podocytes treated with NG. But it was increased in HG treated swiprosin-1 knockdown podocytes compared with that in HG treated control siRNA tranfected podocytes.

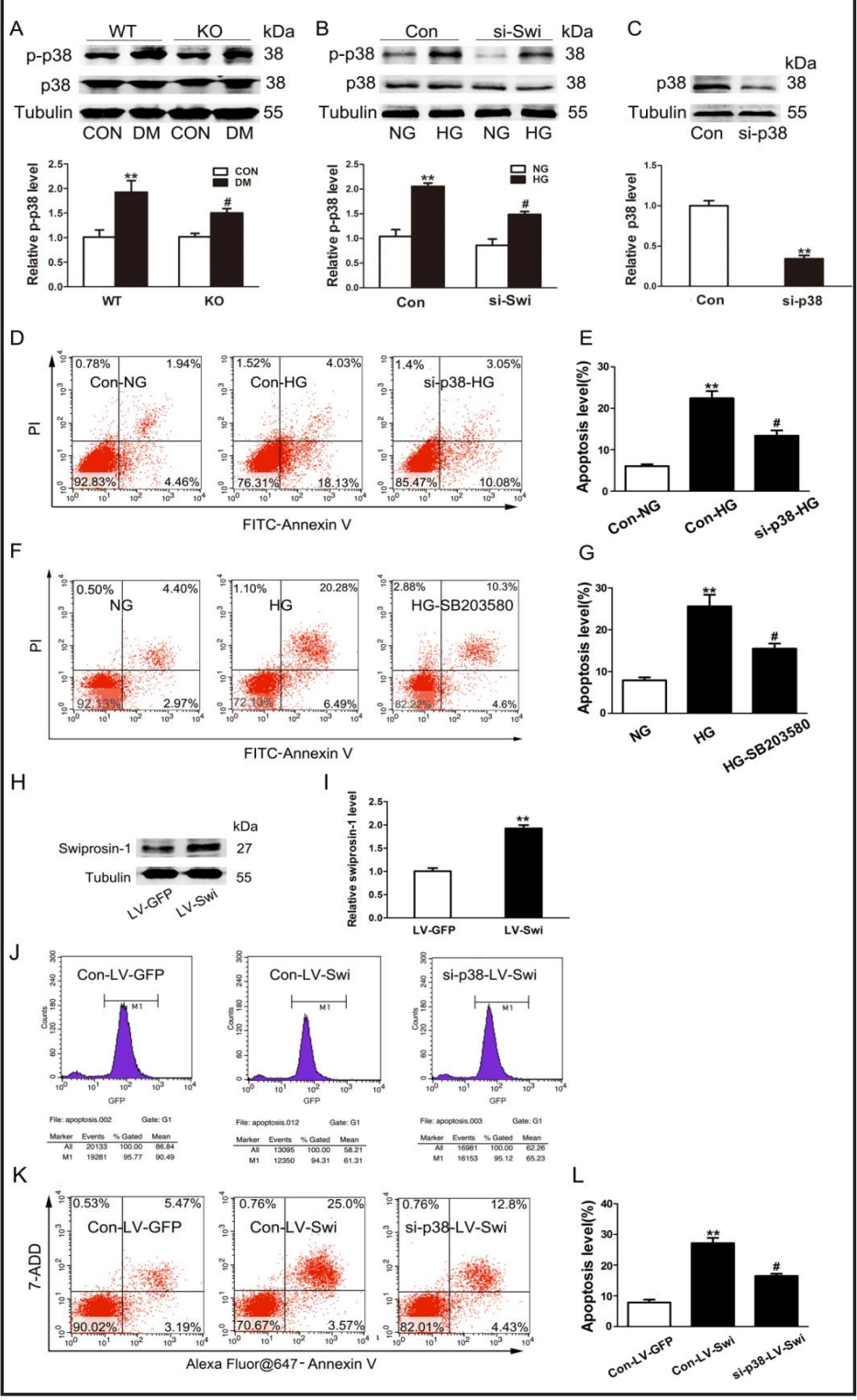


Swiprosin-1 induces podocyte mitochondria-dependent apoptosis via p38 MAPK pathway

As shown in Fig. 9A, there was no significant difference in phosphorylation level of p38 between swiprosin-1\% and swiprosin-1 $1^{+/+}$controls. Compared with swiprosin-1 $^{+/+}$ control mice, the phosphorylation level of p38 was increased in swiprosin- $1^{+/+}$diabetic mice $(1.92 \pm 0.24 v s .1 .00 \pm 0.14)$. However, the phosphorylation level of p38 in the renal cortex of diabetic swiprosin-1\% mice was attenuated as compared with that in swiprosin-1 $1^{+/+}$diabetic mice $(1.50 \pm 0.01 v s .1 .92 \pm 0.24)$. Furthermore, we determined the phosphorylation level of p38 in differentiated MPC-5 cells (Fig. 9B). The phosphorylation level of p38 in HG-treated cells was higher than that in NG-treated cells $(2.05 \pm 0.07 v s .1 .00 \pm 0.14)$. Phosphorylation $p 38$ expression in swiprosin-1 knockdown podocytes showed no significant difference compared with control siRNA transfected cells after NG. Also, we found that knockdown of swiprosin-1 down-regulated phosphorylation of p38 in podocytes stimulated by HG compared with control siRNA transfected cells stimulated by HG $(1.49 \pm 0.06$ vs. $2.05 \pm 0.07)$.

In addition, p38 was knocked down in podocytes using siRNA $(0.34 \pm 0.06$ vs. $1.00 \pm 0.06$, Fig. 9C). As shown in Fig. $9 \mathrm{D}$ and E, the apoptosis level in p38 knockdown podocytes was decreased compared with control siRNA transfected cells after HG stimulation $(13.38 \pm 1.27$ vs. 22.44 \pm 1.72 ). Meanwhile, as shown in Fig. $9 \mathrm{~F}$ and G, p38 MAPK inhibitor SB203580 reduced apoptosis from $25.61 \%$ to $15.50 \%$ in high glucose-induced MPC-5 cells, suggesting

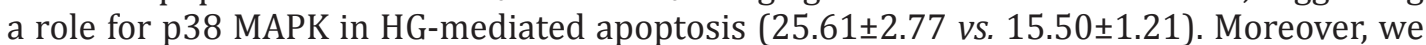
constructed full-length swiprosin-1 (LV-Swi) to over-express swiprosin-1 and LV-GFP as control $(1.92 \pm 0.07 v s .1 .00 \pm 0.07$, Fig. $9 \mathrm{H}$ and I), and detected the transfection efficiency, which was as high as 94\%( Fig. 9J). To exclude the effect of HG, apoptosis level was found to be up-regulated in podocytes overexpressed swiprosin-1 compared with control LVGFP transfected cells (7.84 \pm 0.95 vs. 27.16 \pm 1.73$)$. Targeted knockdown of p38 attenuated the increase of apoptosis level in podocytes overexpressed swiprosin-1 $(16.49 \pm 0.73 \mathrm{vs}$. $27.16 \pm 1.73$, Fig. $9 \mathrm{~K}$ and L).

\section{Discussion}

The present study demonstrated that swiprosin-1 was expressed in podocytes of mouse glomeruli and MPC-5 podocyte cells, swiprosin-1 expression was associated with early-stage DN, and swiprosin-1deficiency reduced podocyte apoptosis in diabetic mice and MPC-5 cells induced by HG. In addition, swiprosin-1 could mediate mitochondria-dependent podocyte apoptosis by activating p38 MAPK pathway in early DN.

Previous studies $[17,20,21]$ showed that swiprosin-1 was widely accumulated in tissues such as the spleen, lung, liver, heart, and brain in particular. Swiprosin-1 was also expressed in immune cells such as human and primary murine mast cells [14], murine B cells, T cells [15-17], macrophages, natural killer cells [18, 19], and human peripheral blood mononuclear cells [20]. Protein atlas database indicates that swiprosin-1 is moderately expressed in human renal glomeruli but not tubules (http://www.proteinatlas.org/ENSG00000142634EFHD2/tissue/kidney\#imid_13574299), which is consistent with the finidng of the present study that swiprosin-1 was moderately expressed in podocytes of renal glomeruli. We also demonstrated that swiprosin-1 was expressed in MPC-5 podocytes and mainly located in the membrane and cytoplasm of differentiated podocytes. In addition, our results clearly showed that the expression of swiprosin-1 in the kidney was up-regulated in diabetic mice treated by STZ in vivo, as well as in podocytes treated with HG in vitro. However, podocytes induced by HG decreased cell viability. Podocyte injury is known to play an important role in the development and progression of DN. These results indicate that increased swiprosin-1 in podocytes may be associated with the progression of DN and podocyte damage induced by HG.

It was reported that the $\mathrm{Ca}^{2+}$-binding cytoskeletal adaptor protein swiprosin-1 could promote apoptosis in activated B cells [22]. In the murine B cell line WEHI231, overexpression of swiprosin-1 enhanced spontaneous and BCR-induced apoptosis and silencing

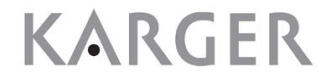


of swiprosin-1 by shRNA augmented survival of WEHI231 cells and suppressed apoptosis following BCR ligation. Many studies revealed that podocyte apoptosis was one of the important characteristics in early DN [38-42]. Clinical analysis of kidney specimens from biopsies of patients with diabetes has shown an obvious reduction in the density of podocytes because of apoptosis or detachment, which was evident in patients with early DN even without microalbuminuria $[43,44]$. Wu et al. [45] reported that podocytes were depleted in diabetic SD rats treated by a single STZ injection (50 mg/kg) at 4, 8 and 12 weeks, which is the earliest cellular anomaly in DN. Gao et al. [46]. also found that podocyte apoptosis level was up-regulated, the number of podocytes was decreased, and proteinuria was increased in STZ-treated 8-week-old diabetic mice, indicating that podocyte apoptosis is a key step in the development of glomerular disease, which results in proteinuria in early-stage DN. In our study, swiprosin-1 knockdown in MPC-5 cells reduced the apoptosis rate induced by $33 \mathrm{mM}$ HG. Consistently, podocyte apoptosis, podocyte foot process effacement, GBM thickening, urinary albumin, and glomerular hypertrophy were attenuated in diabetic mice with swiprosin-1 deficiency. In addition, nephrin and podocin are two important proteins as components of the podocyte foot process or slit diaphragm complex. In Swiprosin-1 knockout diabetic mice, the expression of nephrin and podocin in renal glomeruli was inhibited, and the upregulation of collagen IV, TGF- $\beta$ and fibronectin mRNA in the renal cortex was ameliorated. These results indicate that swiprosin-1 knockout could protect podocytes against HG-induced damage. However, whether the protective role of swiprosin-1 in early DN depends on podocytes remains unclear, and therefore swiprosin-1 conditional knockout mouse models are required in future study.

It was also reported that swiprosin-1 may bind to caspase-9 via Ezrin/Radixin/Moesin (ERM) proteins in human H460 non-small lung cancer cells [24]. ERM proteins are crosslinkers between integral membrane proteins and actin filaments, which are also associated with caspase-9, indicating that swiprosin-1 might be involved in caspase- 9 dependent apoptosis. Consistent with their results, we found that the expression of cleaved-caspase 9 was attenuated in swiprosin-1 knockout diabetic mice and swiprosin-1 knockdown MPC-5 cells treated with HG, suggesting that swiprosin-1 deficiency may inhibit intrinsic apoptosis of podocytes by activating caspase 9 dependent apoptosis. Caspase-8, the major initiator caspase of the death receptor pathway of apoptotic signaling, was unchanged in swiprosin-1 knockout diabetic mice and swiprosin-1 knockdown MPC-5 cells treated with HG, further supporting that swiprosin-1 may induce podocytes apoptosis through the intrinsic apoptotic signaling pathway.

In addition, mitochondria play a critical role in apoptosis by releasing intermembrane space proteins to promote caspase activation [46-49]. It is the result of losing integrity of the outer mitochondrial membrane caused by proapoptotic members of the Bcl-2 family [36, 49, 50]. It was found in our study that activation of the apoptotic pathway was attenuated due to the decreased level of Bax and increased level of Bcl-2 in swiprosin-1 knockout diabetic mice and swiprosin-1 knockdown MPC-5 cells after HG simulation. The low expression of cleaved caspase 3 and 9 indicated the downregulation of podocyte apoptosis because of swiprosin-1 deficiency via the mitochondrial apoptotic pathway induced by hyperglycemia or HG.

Previous studies [22-24, 51] demonstrated that swiprosin-1 was involved in some signaling pathways including NF- $\kappa B$, protein kinaseC $\beta 1 / \eta$, protein kinase $C-\theta$ and Rho family of small GTPases. P38 MAPK is one of the important members of MAPK [52, 53]. Acting as an integration point for multiple biochemical signals, MAPK participates in a wide variety of cellular processes such as proliferation, differentiation and apoptosis [54-56]. The p38 MAPK pathway is known to play an important role in podocyte apoptosis [33, 57]. Adhikary et al. [58] reported that greater numbers of phosphorylated p38 cells were observed in the kidney of diabetic patients by immunohistochemistry compared with those in normal humans, indicating that increased p38 MAPK signaling is a feature of diabetic patients. It was demonstrated that the p38 pathway was activated in the renal cortex of STZ-treated 4-week-old diabetic rats with a reduced number of podocytes, established albuminuria and glomerulosclerosis, suggesting that renal cortical p38 activity was increased in early

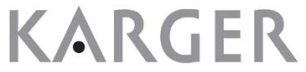


DN, which was correlated with podocyte loss [59]. Sanchez et al. [60] demonstrated that phosphorylation level of p38 MAPK was increased in HG (30 mM)-induced human podocyte apoptosis, and SB203580 (p38 MAPK inhibitor) suppressed podocyte apoptosis induced by HG. Consistent with these studies, our results showed that phosphorylation level of p38 was increased in the renal tissue of diabetic mice and in HG-induced podocytes. Furthermore, treatment with siRNA against p38 MAPK and p38 inhibitor SB203580 reduced apoptosis in HG-induced MPC-5 cells. These findings suggested that p38 MAPK played a role in HGmediated podocyte apoptosis. Moreover, we found that the phosphorylation level of p38 as well as podocyte apoptosis were inhibited in swiprosin-1 knockout diabetic mice and swiprosin-1 knockdown MPC- 5 cells treated with HG. These results implied that swiprosin-1 might promote podocyte apoptosis via activation of p38 MAPK signaling pathway. In addition, targeted knockdown of p38 in podocytes inhibited podocyte apoptosis which was promoted by over-expression of swiprosin-1. Therefore, our study suggested that swiprosin-1 might be upstream of p38 MAPK to regulate podocyte apoptosis. However, we cannot draw a conclusion that the increased podocyte apoptosis is totally due to activation of p38 MAPK signaling pathway by swiprosin-1. It was possible that p38 MAPK was activated by not only the increase of swiprosin-1 but also HG in HG-induced podocyte apoptosis. How swiprosin-1 regulates the p38 MAPK signaling pathway in podocyte apoptosis in early-stage DN needs further investigation.

\section{Conclusion}

We found that upregulation of swiprosin-1 in early DN promoted mitochondriadependent podocyte apoptosis by activating p38 MAPK signaling pathway. This finding highlights the important role of swiprosin- 1 in podocyte apoptosis. It seems reasonable to suggest that the development and application of swiprosin-1 inhibitors may be a new target for the treatment of DN patients, especially in the early stage.

\section{Acknowledgements}

We thank Tong-Hui Ma (Dalian Medical University, China) and Wei-Heng Su (Jilin University, China) for constructing swiprosin-1 knockout mouse. This study was supported by grants from the National Natural Science Foundation of China (No. 81473258, 81273504, 81402941), grant from Shanghai Municipal Commission of Health and Family Planning (No. 20144Y0204, 201540294) and sponsored by Natural Science Foundation of Shanghai (No. 16ZR1434400, 15140904600).

\section{Disclosure Statement}

The authors declare that there is no duality of interest associated with this manuscript.

\section{References}

\footnotetext{
1 Wasik AA, Dumont V, Tienari J, Nyman TA, Fogarty CL, Forsblom C, Markku L, Eero L,Per-Henrik G, Sanna L: Septin 7 reduces nonmuscle myosin IIA activity in the SNAP23 complex and hinders GLUT4 storage vesicle docking and fusion. Exp Cell Res 2017; 350:336-348.

-2 Huang G, Lv J, Li T, Huai G, Li X, Xiang S, Long W, Zhen Q, Jian P, Zou B, Wang Y: Notoginsenoside R1 ameliorates podocyte injury in rats with diabetic nephropathy by activating the PI3K/Akt signaling pathway. Int J Mol Med 2016;38:1179-1189.
} 


\section{Cellular Physiology Cell Physiol Biochem 2018;45:899-916 and Biochemistry DOI: 10.1159/000487285 0 Published 2018 (O) 2018 The Author(s). Published by S. Karger AG, Basel

3 Zhang Y, Gao X, Chen S, Zhao M, Chen J, Liu R, Sheng C, Meng Q, Wang S, Liu W: Cyclin-dependent kinase 5 contributes to endoplasmic reticulum stress induced podocyte apoptosis via promoting MEKK1 phosphorylation at Ser280 in diabetic nephropathy. Cell Signal 2016;31:31-40.

4 Xin W, Li Z, Xu Y, Yu Y, Zhou Q, Chen L, Wan Q: Autophagy protects human podocytes from high glucoseinduced injury by preventing insulin resistance. Metabolism 2016;65:1307-1315.

-5 Eid S, Boutary S, Braych K, Sabra R, Massaad C, Hamdy A, Rashid A, Moodad S, Block K, Gorin Y, Abboud HE, Eid AA: mTORC2 signaling regulates Nox4-induced podocyte depletion in diabetes. Antioxid Redox Signal 2016;25:703-719.

-6 Tan H, Yi H, Zhao W, Ma J, Zhang Y, Zhou X: Intraglomerular crosstalk elaborately regulates podocyte injury and repair in diabetic patients insights from a 3D multiscale modeling study. Oncotarget 2016;7:7313073146.

7 Holderied A, Romoli S, Eberhard J, Konrad LA, Devarapu SK, Marschner JA, Muller S, Anders HJ: Glomerular parietal epithelial cell activation induces collagen secretion and thickening of Bowman's capsule in diabetes. Lab Invest 2015;95:273-282.

-8 Gruden G, Perin PC, Camussi G: Insight on the pathogenesis of diabetic nephropathy from the study of podocyte and mesangial cell biology. Current Diabetes Reviews 2005;1: 27-40.

-9 Wang B, Xu X, He X, Wang Z, Yang M: Berberine improved Aldo-induced podocyte injury via inhibiting oxidative stress and endoplasmic reticulum stress pathways both in vivo and in vitro. Cell Physiol Biochem 2016;39:217-228.

10 Gluhovschi C, Gluhovschi G, Petrica L, Timar R, Velciov S, Ionita I, Kaycsa A, Timar B: Urinary biomarkers in the assessment of early diabetic nephropathy. J Diabetes Res DOI: 10.1155/2016/4626125.

11 Wang C, Liu X, Ke Z, Tang Y, Li CC, Li CM, Ye Z, Zhang J, Lou T: Mesangial medium from IgA nephropathy patients induces podocyte epithelial-to-mesenchymal transition through activation of the phosphatidyl Inositol-3-kinase/Akt signaling pathway. Cell Physiol Biochem 2012;29:743-752.

-12 Zhang H, Luo W, Sun Y, Qiao Y, Zhang L, Zhao Z, Lv S: Wnt/ $\beta$-Catenin signaling mediated-UCH-L1 expression in podocytes of diabetic nephropathy. Int J Mol Sci DOI: 10.3390/ijms17091404.

13 Liu F, Zong M, Wen X, Li X, Wang J, Wang Y, Jiang W, Li X, Guo Z, Qi H: Silencing of histone deacetylase 9 expression in podocytes attenuates kidney injury in diabetic nephropathy. Sci Rep DOI: 10.1038/ srep33676.

14 Vuadens F, Rufer N, Kress A, Corthesy P, Schneider P, Tissot JD: Identification of swiprosin 1 in human lymphocytes. Proteomics 2004;4:2216-2220.

15 Mielenz D, Vettermann C, Hampel M, Lang C, Avramidou A, Karas M, Jäck HM: Lipid rafts associate with intracellular B cell receptors and exhibit a B Cell stage-specific protein composition. The Journal of Immunology 2005;174:3508-3517.

16 Brachs S, Turqueti-Neves A, Stein M, Reimer D, Brachvogel B, Bösl M, Winkler T, Voehringer D, Jäck HM, Mielenz D: Swiprosin-1/EFhd2 limits germinal center responses and humoral type 2 immunity. Eur J Immunol 2014;44:3206-3219.

-17 Kwon MS, Park KR, Kim YD, Na BR, Kim HR, Choi HJ, Piragyte I, Jeon H, Chung KH, Song WK, Eom SH, Jun CD: Swiprosin-1 is a novel actin bundling protein that regulates cell spreading and migration. PLoS One DOI: 10.1371/journal.pone.0071626.

18 Ramesh TP, Kim YD, Kwon MS, Jun CD, Kim SW: Swiprosin-1 regulates cytokine expression of human mast cell line HMC-1 through actin remodeling. Immune Netw 2009;9:274-284.

19 Park KR, Kwon MS, An JY, Lee JG, Youn HS, Lee Y, Jun CD, Kang JY, Kim TG, Lim JJ, Park JS, Lee SH, Song WK, Cheong HK, Eom SH: Structural implications of Ca2+-dependent actin-bundling function of human EFhd2/ Swiprosin-1 Sci Rep DOI: 10.1038/srep39095.

-20 Purohit P, Perez-Branguli F, Prots I, Borger E, Gunn-Moore F, Welzel O, Loy K, Wenzel EM, Gromer TW, Brachs S, Holzer M, Buslei R, Fritsch K, Martin R, Bohm KJ, Winner B, Mielenz D: The Ca2+ sensor protein swiprosin-1/EFhd2 is present in neurites and involved in kinesin-mediated transport in neurons. PLoS One 2014;18:e103976.

21 Thylur RP, Kim YD, Kwon MS, Oh HM, Kwon HK, Kim SH, Im SH, Chun JS, Park ZY, Jun CD: Swiprosin-1 is expressed in mast cells and up-regulated through the protein kinase $C \beta 1 / \eta$ pathway. J Cell Biochem 2009;108:705-715.

22 Avramidou A, Kroczek C, Lang C, Schuh W, Jack HM, Mielenz D: The novel adaptor protein Swiprosin-1 enhances BCR signals and contributes to BCR-induced apoptosis. Cell Death Differ 2007;14:1936-1947. 


\section{Cellular Physiology Cell Physiol Biochem 2018;45:899-916 and Biochemistry DOI: 10.1159/000487285 0 Published 2018 (O) 2018 The Author(s). Published by S. Karger AG, Basel

23 Kim YD, Kwon MS, Na BR, Kim HR, Lee HS, Jun CD: Swiprosin-1 expression is up-regulated through protein kinase C- $\theta$ and NF-kappaB pathway in T cells. Immune Netw 2013;13:55-62.

-24 Checinska A, Giaccone G, Rodriguez JA, Kruyt FA, Jimenez CR: Comparative proteomics analysis of caspase9-protein complexes in untreated and cytochrome c/dATP stimulated lysates of NSCLC cells. J Proteomics 2009;72:575-585.

-25 Wang ZB, Han P, Tong LC, Luo Y, Su WH, Wei X1,Yu XH,Liu WY, Zhang XH, Lei H, Li ZZ, Wang F, Chen JG, Ma TH, Su DF, Li L1: Low level of swiprosin-1/EFhd2 in vestibular nuclei of spontaneously hypersensitive motion sickness mice. Sci Rep DOI: 10.1038/srep40986.

-26 Schiffer M, Bitzer M, Roberts ISD, Kopp JB, Dijke P, Mundel P, Bottinger EP:Apoptosis in podocytes induced by TGF- $\beta$ and Smad7 Journal of Clinical Investigation 2001;108:807-816.

-27 Li G, Li CX, Xia M, Ritter JK, Gehr TW, Boini K, Li PL: Enhanced epithelial-to-mesenchymal transition associated with lysosome dysfunction in podocytes: role of p62/Sequestosome 1 as a signaling hub. Cell Physiol Biochem 2015;35:1773-1786.

28 Brem AS, Gong R: Therapeutic targeting of aldosterone: a novel approach to the treatment of glomerular disease. Clin Sci (Lond) 2015;128:527-535.

29 Chen T, Zheng LY, Xiao W, Gui D, Wang X, Wang N. Emodin ameliorates high glucose induced-podocyte epithelial-mesenchymal transition in-vitro and in-vivo. Cell Physiol Biochem. 2015;35(4):1425-1436.

30 Xia S, Liu Y, Li X, Thilo F, Tepel M: Insulin increases expression of TRPC6 channels in podocytes by a calcineurin-dependent pathway. Cell Physiol Biochem 2016;38:659-669.

-31 Zhang HT, Wang WW, Ren LH, Zhao XX, Wang ZH, Zhuang DL, Bai YN: The mTORC2/Akt/NFkB pathwaymediated activation of TRPC6 participates in Adriamycin-induced podocyte apoptosis. Cell Physiol Biochem 2016;40:1079-1093.

-32 Soetikno V, Arozal W, Louisa M, Setiabudy R: New insight into the molecular drug target of diabetic nephropathy. Int J Endocrinol DOI: 10.1155/2014/968681.

-33 Lim E, Lim JY, Kim E, Kim YS, Shin JH, Seok PR, Jung S, Yoo SH, Kim Y: Xylobiose, an alternative sweetener, ameliorates diabetes-related metabolic changes by regulating hepatic lipogenesis and miR-122a/33a in db/db mice. Nutrients 2016; 5; pii: E791.

-34 Cui F, Gao Y, Zhao W, Zou D, Zhu Z, Wu X, Tian N, Wang X, Liu J, Tong Y: Effect of Tongxinluo on podocyte apoptosis via inhibition of oxidative stress and P38 pathway in diabetic rats. Evid Based Complement Alternat Med DOI: 10.1155/2016/5957423.

35 Liu WT, Peng FF, Li HY, Chen XW, Gong WQ, Chen WJ, Chen Y, Li PL, Li ST, Xu ZZ, Long HB: Metadherin facilitates podocyte apoptosis in diabetic nephropathy. Cell Death Dis DOI: 10.1038/cddis.2016.335.

-36 Li W, Wang Q, Du M, Ma X, Wu L, Guo F, Zhao S, Huang F, Wang H, Qin G: Effects of overexpressing FoxO1 on apoptosis in glomeruli of diabetic mice and in podocytes cultured in high glucose medium. Biochem Biophys Res Commun 2016;478:612-617.

-37 Wartiovaara J, Ofverstedt LG, Khoshnoodi J, Zhang J, Mäkelä E, Sandin S, Ruotsalainen V, Cheng RH, Jalanko H, Skoglund U, Tryggvason K: Nephrin strands contribute to a porous slit diaphragm scaffold as revealed by electron tomography. Journal of Clinical Investigation 2004;114:1475-1483.

-38 Anil Kumar P, Welsh GI, Saleem MA, Menon RK: Molecular and cellular events mediating glomerular podocyte dysfunction and depletion in diabetes mellitus. Front Endocrinol (Lausanne) DOI: 10.3389/ fendo.2014.00151.

-39 Wang ZS, Xiong F, Xie XH, Chen D, Pan JH, Cheng L: Astragaloside IV attenuates proteinuria in streptozotocin-induced diabetic nephropathy via the inhibition of endoplasmic reticulum stress. BMC Nephrol DOI: 10.1186/s12882-015-0031-7.

40 De Cosmo S, Menzaghi C, Prudente S, Trischitta V: Role of insulin resistance in kidney dysfunction: insights into the mechanism and epidemiological evidence. Nephrol Dial Transplant 2013; 28:29-36.

41 Chang JH, Paik SY, Mao L, Eisner W, Flannery PJ, Wang L,Tang Y, Mattocks N, Hadjadj S, Goujon JM, Ruiz P, Gurley SB, Spurney RF: Diabetic kidney disease in FVB/NJ Akita Mice: temporal pattern of kidney injury and urinary nephrin excretion. PLoS One DOI: 10.1371/journal.pone.0033942.

42 Zhang L, Li R, Shi W, Liang X, Liu S, Ye Z, Yu C, Chen Y, Zhang B,Wang W, Lai Y, Ma J, Li Z, Tan X: NFAT2 inhibitor ameliorates diabetic nephropathy and podocyte injury in $\mathrm{db} / \mathrm{db}$ mice. Br J Pharmacol 2013;170:426-439.

43 Bhatti AB, Usman M: Drug targets for oxidative podocyte injury in diabetic nephropathy. Cureus DOI: 10.7759/cureus.393. 


\section{Cellular Physiology Cell Physiol Biochem 2018;45:899-916 and Biochemistry DOI: 10.1159/000487285 010 Published 2018 The Author(s). Published by S. Karger AG, Basel

44 Wolf G, Chen S, Ziyadeh F N: From the periphery of the glomerular capillary wall toward the center of disease. Diabetes 2005;54:1626-1634.

45 Wu W, Zhang M, Ou S, Liu X, Xue L, Liu J, Wu Y, Li Y, Liu Q: Early protective role of MST1 knockdown in response to experimental diabetic nephropathy. Am J Transl Res 2016;8:1397-1411.

-46 Gao F, Yao M, Cao Y, Liu S, Liu Q, Duan H: Valsartan ameliorates podocyte loss in diabetic mice through the Notch pathway. Int J Mol Med 2016;37:1328-1336.

-47 Yu L, Liu Y, Wu Y, Liu Q Feng J, Gu X, Xiong Y, Fan Q, Ye J: Smad3/Nox4-mediated mitochondrial dysfunction plays a crucial role in puromycin aminonucleoside-induced podocyte damage. Cell Signal 2014;26:29792991.

48 Yu W, Shen T, Liu B, Wang S, Li J, Dai D, Cai J, He Q: Cardiac shock wave therapy attenuates H9c2 myoblast apoptosis by activating the AKT signal pathway. Cell Physiol Biochem 2014;33:1293-1303.

49 Wan C, Chen Y, Yin P, Han D, Xu X, He S, Liu M, Hou X, Liu F, Xu J: Transport stress induces apoptosis in rat myocardial tissue via activation of the mitogen-activated protein kinase signaling pathways. Heart Vessels 2016;31:212-221.

50 Chen J, Chen JK, Harris RC: EGF receptor deletion in podocytes attenuates diabetic nephropathy. J Am Soc Nephrol 2015;26:1115-1125.

51 Huh YH, Oh S, Yeo YR, Chae IH, Kim SH, Lee JS, Yun SJ, Choi KY, Ryu JH, Jun CD, Song WK: Swiprosin-1 stimulates cancer invasion and metastasis by increasing the Rho family of GTPase signaling. Oncotarget 2015;6:13060-13071.

52 Roux PP, Blenis J: ERK and p38 MAPK-activated protein kinases: a family of protein kinases with diverse biological functions. Microbiol Mol Biol Rev 2004;68:320-344.

-53 Cargnello M, Roux PP: Activation and function of the MAPKs and their substrates, the MAPK-activated protein kinases. Microbiol Mol Biol Rev 2011;75:50-83.

54 Ho PJ, Chou CK, Yeh SF: Role of JNK and p38 MAPK in Taiwanin A-induced cell death. Life Sci 2012;91:13581365.

-55 Yang XH, Pan Y, Zhan XL, Zhang BL, Guo LL, Jin HM: Epigallocatechin-3-gallate attenuates renal damage by suppressing oxidative stress in diabetic db/db mice. Oxid Med Cell Longev DOI: 10.1155/2016/2968462.

56 Wang L, Bai YY, Yang Y, Hu F, Wang Y, Yu Z, Cheng Z, Zhou J: Diabetes mellitus stimulates pancreatic cancer growth and epithelial-mesenchymal transition-mediated metastasis via a p38 MAPK pathway. Oncotarget 2016;7: 38539-38550.

57 Chuang PY, Yu Q, Fang W, Uribarri J, He JC: Advanced glycation endproducts induce podocyte apoptosis by activation of the FOXO4 transcription factor. Kidney Int 2007;72:965-976.

58 Adhikary L, Chow F, Nikolic-Paterson DJ, Stambe C, Dowling J, Atkins RC, Tesch GH: Abnormal p38 mitogenactivated protein kinase signalling in human and experimental diabetic nephropathy. Diabetologia 2004;47:1210-1222.

59 Komers R, Lindsley JN, Oyama TT, Cohen DM, Anderson S: Renal p38 MAP kinase activity in experimental diabetes. Lab Invest 2007;87:548-558.

60 Sanchez-Niño MD, Sanz AB, Ihalmo P, Lassila M, Holthofer H, Mezzano S, Aros C, Groop PH, Saleem MA, Mathieson PW, Langham R, Kretzler M, Nair V, Lemley KV, Nelson RG, Mervaala E, Mattinzoli D, Rastaldi MP, Ruiz-Ortega M, Martin-Ventura JL, Egido J, Ortiz A: The MIF receptor CD74 in diabetic podocyte injury. J Am Soc Nephrol 2009;20:353-362. 